\title{
Aversive stimulation during the stress-hyporesponsive period does not affect the number of corticotroph cells in neonatal male rats
}

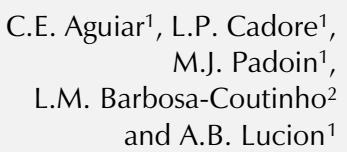

\author{
1Departamento de Fisiologia, Instituto de Ciências Básicas da Saúde, \\ Universidade Federal do Rio Grande do Sul, Porto Alegre, RS, Brasil \\ ${ }^{2}$ Departamento de Patologia, Fundação Faculdade Federal de Ciências \\ Médicas de Porto Alegre, Porto Alegre, RS, Brasil
}

\author{
Correspondence \\ A.B. Lucion \\ Departamento de Fisiologia \\ ICBS, UFRGS \\ Rua Sarmento Leite, 500 \\ 90050-170 Porto Alegre, RS \\ Brasil \\ E-mail: alucion@vortex.ufrgs.br \\ Presented at the XII Annual Meeting \\ of the Federação de Sociedades de \\ Biologia Experimental, Caxambu, \\ MG, Brasil, August 27-30, 1997. \\ Research supported by FAPERGS, \\ FINEP, CAPES and CNPq.
}

Received April 15, 1997 Accepted October 20, 1997

\begin{abstract}
Immunohistochemistry was used to evaluate the effects of neonatal handling and aversive stimulation during the first 10 days of life on the number of corticotrophs in the anterior lobe of the pituitary of 11-dayold male Wistar rats. Since adult rats handled during infancy respond with reduced corticosterone secretion in response to stressors and with less behavior inhibition in novel environments, we assumed that neonatal stimulation could affect pituitary morphology during this critical period of cell differentiation. Three groups of animals were studied: intact (no manipulation, $\mathrm{N}=5$ ), handled $(\mathrm{N}=5)$ and stimulated (submitted to 3 different aversive stimuli, $N=5$ ). The percentage of ACTH-immunoreactive cells in the anterior lobe of the pituitary (number of ACTH-stained cells divided by total number of cells) was determined by examining three slices per pituitary in which a minimum of 200 cells were counted by two independent researchers. Although animals during the neonatal period are less reactive to stresslike stimulation in terms of ACTH and corticosterone secretion, results showed that the relative number of ACTH-stained cells of neonatal handled $(0.25 \pm 0.01)$ and aversive stimulated $(0.29 \pm 0.03)$ rats was not significantly different from intact $(0.30 \pm 0.03)$ animals. Neonatal stimulation may have a differential effect on the various subpopulations of corticotroph cells in the anterior pituitary.
\end{abstract} Key words - ACTH

- Immunohistochemistry

- Pituitary

- Neonatal handling

- Stress
Neonatal experience has long-lasting effects on emotional behavior and stress reactivity of adult animals $(1,2)$. Neonatal stimulation has been used as an experimental model to examine mechanisms by which early environmental changes may affect neural systems leading to behavioral and endocrine stable alterations $(1,2)$. In rats, neonatal stimulation typically consists of handling pups during the first two weeks of life. In adulthood, the apparently harmless procedure during infancy reduces fearfulness to novel environments and corticosterone secretion in response to stressors $(3,4)$. Handling the pups during this "critical period" affects the animal throughout its life $(5,6)$.

Basal plasma levels of ACTH are very low in rats during infancy and the stimula- 
tion of pups produces only a mild increase or no change in ACTH or corticosterone, depending on the intensity and the nature of the stimulus (6-8). Therefore, this period is called the stress-hyporesponsive period $(5,6)$. Several studies have been conducted to identify the site(s) of this insensitivity or immaturity $(9,10)$. Immunocytochemical studies have demonstrated that ACTH cells can be distinguished as early as at 14-16 days of fetal age in rats (11). The pituitary is functionally responsive to certain stressors until 1-2 days after birth, but then ACTH levels decrease to a minimal level until postnatal days 10-11 $(7,9,10)$.

The purpose of the present study was to determine the effect of neonatal aversive stimulation during the first 10 days of life on the number of corticotroph cells in the pituitary of 11-day-old male rats. In recent studies, our laboratory has investigated the effects of either a mild or a more noxious stimulation of pups during the hyporesponsive period on several behaviors of adult rats $(12,13)$. These studies showed some differential effects on adult behavior between neonatal handling and aversive stimulation (cold, for instance, has a more prominent decrement effect on sexual behavior than handling). The aim of the present investigation was to immunohistochemically determine the number of the developing corticotroph cells of male rats submitted to two different types of stimulation.

Male Wistar rats were used. From the 1st to the 10th postpartum day, the entire offspring of a mother was submitted to one of the following procedures: pups were left undisturbed (intact animals), handled or stimulated. Handling consisted of separating the pups from the mother and gently manipulating them for about $1 \mathrm{~min}$. Stimulated animals were separated from the mother, put together in a small plastic box taken to a different room and submitted to low temperature $\left(0^{\circ} \mathrm{C}\right)$, light stimulation with a $60-\mathrm{W}$ bulb placed $30 \mathrm{~cm}$ above the offspring, or continuous sound stimulation $(90 \mathrm{~dB})$ for 10 min per day randomly distributed during 10 days. Immediately after being handled or stimulated, the animals were returned to their mothers in the home cage. On the 11th postpartum day, animals from different mothers in each group (intact, handled and stimulated) were killed by decapitation between 12:00 and 15:00 $\mathrm{h}$. The pituitary glands were removed rapidly, fixed in formalin and embedded in paraffin. Serial sections $(4.0 \mu \mathrm{m})$ of the pituitary were obtained and every tenth section was stained with hematoxylin-eosin to determine the area of the pituitary to be analyzed immunohistochemically. Three slides per pituitary were chosen so that the sectioned fields were 8-12 $\mu \mathrm{m}$ apart to avoid duplicate counts of the same cell. Immunohistochemistry was performed using the rabbit polyclonal antibody to ACTH (1:500; anti-hACTH-IC-2, AFP-39013082 (rabbit) NIDDK/NHPP) and the avidin-biotin complex (ABC) stain described elsewhere (14). The sections were counterstained with hematoxylin. A region of high density but with still clearly visible individual positive cells in the anterior lobe of the pituitary was analyzed in each section. Counts of nucleated cells were performed with a $40 \mathrm{X}$ objective lens and a 10X ocular microscope. Using a grid lens, two experienced investigators separately counted a total of more than 200 cells and the number of ACTH-stained cells is reported as percent of the total cells. The individual percentage was averaged among the 3 sections per pituitary and between the two investigators. Five pituitary glands per group were studied. Data are reported as the mean $( \pm$ SEM $)$ for each group and were compared by ANOVA, with the level of significance set at $\mathrm{P}<0.05$.

Since adult rats stimulated during infancy respond differently to stress than non-stimulated ones $(2,4,7,8)$, we assumed that neonatal handling and/or aversive stimulation would affect pituitary morphology during this critical period of cell differentiation. 
However, the results shown in Figure 1 do not allow us to reject the null hypothesis. The averages of the relative number of ACTH-stained cells for each of the 3 groups analyzed were not significantly different $(\mathrm{F}(2,12)=0.9961, \mathrm{P}=0.40$, ANOVA $)$. Specifically, the mean value for the handled group was lower than that of the intact group, but did not reach a significant difference ( $\mathrm{P}=0.39$, Newman-Keuls post-hoc test). Also, the percentage of ACTH-stained cells in the pituitary of intact (control) male rats at the age of 11 days in the present study was the same as that reported for adult animals (15). This comparison agrees with the results of another study (9) which also found no difference between the number of ACTHpositive cells in the pituitary of intact 11day-old and adult rats. Although the amount of ACTH secretion is different in non-stimulated neonatal and adult rats $(7,9,16,17)$, the density of corticotrophs in the anterior lobe of the pituitary appears to be the same.

During the neonatal stress-hyporesponsive period, although the animals were less reactive to a variety of aversive stimuli in terms of plasma ACTH levels and corticosterone secretion $(5,6,16)$, the present results showed that 11-day-old rats previously stimulated do possess cells that produce ACTH, and that the number of ACTH-stained cells was not affected by the stress-like stimulation. It appears that ACTH synthesis is impaired during the neonatal period due to an unknown mechanism. On the other hand, neonatal stimulation may have specifically affected the ratio between two populations of ACTH-immunoreactive cells in the gland (9). Two types of cells have been described: the stellate cells that store ACTH alone, and the ovoid or round corticotrophs that store gonadotrophins as well as ACTH (9). In the present study there might have been a shift in

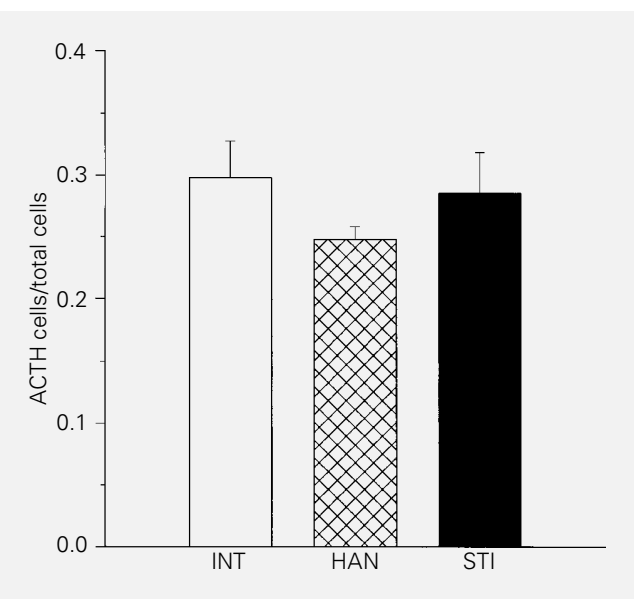

the proportion of stellate and round cells due to neonatal stimulation. Nevertheless, any change in the subpopulation of round cells should be followed by an inverse change in the subpopulation of stellate cells, since the whole population of corticotrophs was not affected by the stimulation.

In conclusion, apparently neither handling nor aversive stimulation during the first 10 days of life alters the number of corticotrophs in the anterior pituitary lobe of 11-day-old male rats. Experiments are being carried out in our laboratory to determine the effects of neonatal stimulation on the number of corticotrophs in females. There are some indications (16) that aversive stimulation during the neonatal stress-hyporesponsive period may differently affect ACTH secretion in males and females.

\section{Acknowledgments}

We thank Dr. A.F. Parlow (Pituitary Hormones \& Antisera Center, Harbor-UCLA Medical Center, California, USA) for the antisera. We also thank Isabel C.L. de Moura and Mario S.M. Pereira for technical assistance.
Figure 1 - Relative number of corticotroph cells (number of ACTH-antibody-stained cells divided by total number of cells) in the anterior lobe of the pituitary of 11-day-old male rats. The results are reported as means \pm SEM for 600 cells/pituitary. Each group represents the average of 5 pituitaries. Intact (INT) control rats suffered no previous manipulation, handled (HAN) rats were gently manipulated for 1 min during the previous 10 days, and stimulated (STI) rats were submitted to cold, direct light or intense sound for 10 min during the same period. No statistically significant difference was observed between groups (ANOVA). 


\section{References}

1. Denenberg VH (1964). Critical periods, stimulus input, and emotional reactivity: a theory of infantile stimulation. Psychological Review, 71: 335-351.

2. Levine S (1962). Plasma-free corticosteroid response to electric shock in rats stimulated in infancy. Science, 135: 795799.

3. Levine S (1993). The psychoendocrinology of stress. Annals of the New York Academy of Sciences, 697: 61-69.

4. Meaney MJ, Seema B, Larocque S, McCormick C, Shanks N, Sharma S, Smythe J, Viau V \& Plotsky PM (1993). Individual differences in the hypothalamic-pituitary-adrenal stress response and the hypothalamic crf system. Annals of the New York Academy of Sciences, 697: 70-85.

5. Gould E (1994). The effects of adrenal steroids and excitatory input on neuronal birth and survival. Annals of the New York Academy of Sciences, 743: 73-93.

6. Levine $S$ (1994). The ontogeny of the hypothalamic-pituitary-adrenal axis. The influence of maternal factors. Annals of the New York Academy of Sciences, 746: 275-293.

7. Walker $C D$, Perrin $M$, Vale $W$ \& Rivier $C$ (1986). Ontogeny of the stress response in the rat: role of the pituitary and the hypothalamus. Endocrinology, 118: 14451451.
8. Bhatnagar S \& Meaney MJ (1995). Hypothalamic-pituitary-adrenal function in chronic intermittently cold-stressed neonatally handled and nonhandled rats. Journal of Neuroendocrinology, 7: 97-108.

9. Childs GV, Ellison DG \& Ramaley JA (1982). Storage of anterior lobe adrenocorticotropin in corticotropes and a subpopulation of gonadotropes during the stress-nonresponsive period in the neonatal male rat. Endocrinology, 110: 16761692.

10. Guillet $R$, Saffran $M$ \& Michaelson SM (1980). Pituitary-adrenal response in neonatal rats. Endocrinology, 106: 991-994.

11. Khachaturian H, Kwak SP, Shaefer MKH \& Watson SJ (1991). Pro-opiomelanocortin mRNA and peptide co-expression in developing rat pituitary. Brain Research Bulletin, 26: 195-201.

12. Charchat $H$, Padoin $M J$ \& Lucion $A B$ (1995). Efeito do estresse crônico neonatal sobre o comportamento de ratos adultos no campo aberto com 0 gato. $X$ Annual Meeting of the Federação de Sociedades de Biologia Experimental, 46 (Abstract).
13. Padoin $M J$, Cadore LP \& Lucion $A B$ (1995). Efeito do estresse crônico neonatal sobre o comportamento sexual de machos e agressivo maternal de ratos. $X A n-$ nual Meeting of the Federação de Sociedades de Biologia Experimental, 36 (Abstract).

14. Barbosa-Coutinho LM (1988). Adenomas da hipófise: estudo imuno-histoquímico. Doctoral thesis, Universidade Federal do Rio Grande do Sul, Curso de Pós-Graduação em Clínica Médica, Porto Alegre, RS.

15. Castro $M$, Figueiredo $F \&$ Moreira $A C$ (1995). Time-course of hypothalamic $\mathrm{CRH}$ and pituitary ACTH contents, and pituitary responsiveness to $\mathrm{CRH}$ stimulation after bilateral adrenalectomy. Hormone and Metabolic Research, 27: 10-15.

16. Tang F \& Phillips JG (1977). Pituitary-adrenal response to ether stress in the neonatal rat. Journal of Endocrinology, 75: 183184.

17. Krieger DT, Liotta AS, Brownstein MJ \& Zimmerman EA (1980). ACTH, ß-lipotropin, and related peptides in brain, pituitary, and blood. Recent Progress in Hormone Research, 36: 277-344. 